\title{
ASSESSING NIGERIAN POLITICAL LEADERSHIP WITH A DEMOCRATIC PARADIGM
}

\author{
Ignatius C. Uzondu* \\ http://dx.doi.org/10.4314/og.v15i1.4s
}

\begin{abstract}
A sober reflection or speculation on African leadership portrays the practice of authentic democracy as a perennial problem in Nigeria and in African continent. Democratic/electoral process is where citizens choose representatives in government by means of free, fair, contested and regularly scheduled elections and where adults have the right to vote and their votes count. But Nigerian democracy lacks basic trust. It is really a universal problem but Africans and Nigerians in particular got larger portion as our democratic practice is very poor. The citizens should be the starting point and focus of democracy, but this is not the case in Nigeria as many political and elected elites represent their business interest. This democratic deficit or deficiency is seen in local, state and federal levels of Nigerian government and this leads gradually to a serious decline in citizen's active participation or active citizenship. Using expository and analytic method of inquiry, we found out that Nigerians and Africans may have been drifting from this form of government due to some of its demerit. Again, Africa has been long known for its communitarian living/communalism which we found to have enormous similarities with democracy though the difference is clear. Corruption, bad leadership, lack of originality and the likes are the causes of lack of authentic democratic practice and leadership in Africa and in Nigeria. Finally, this study concludes that the dividends of authentic democracy will be fully evident and rooted in Nigeria and Africa only when we embrace democracy in full.
\end{abstract}

Keywords: Political leadership, Democracy, Communalism

\section{Introduction}

In attempt to know more on Africa and political leadership, we focus particularly on Nigeria; a country located on the western coast of Africa and is still in the state of underdevelopment suffered much on political instability or lack of continuity in government, bad 
leadership which gave rise to economic and technological stagnation, insecurity and the likes. In her journey towards democracy, she had her first republic beginning on $16^{\text {th }}$ January, 1963 and a military coup brought Major Gen. Johnson Aguiyi-Ironsi to power terminating the first period of democratic rule in 1966. Trapping of a democratic state were seen in Nigeria at independence; the country had a federal constitution that ensured a large measure of autonomy to the regions existing then. The country was practicing parliamentary democracy modeled along British lines that stressed majority rule. Unlike many African states which adopted one-party system, Nigeria had a functional, albeit regionally based, multiparty system. Despite these democratic trappings of the $1^{\text {st }}$ republic, it contained some fundamental and structural weaknesses that made sure that the republic did not survive. One significant weakness is the disproportionate power of the North in the federation. There was the regional power in-balance. Another weakness found was the AG leadership crisis that led to the balkanization of the western region. The lack of freedom and fairness of the 1964 elections was the final straw that broke the camel's back, the fall of the first republic.

The second republic followed from 1979 - 1983, with Shehu Shagari as the elected president; It felled as a result of massive corruption and administrative incompetence. The military intervened to stop corrupt politicians whose actions grossly undermined government's efforts.

The third republic (1992 - 1993) was an unsuccessful attempt by General Ibrahim Babangida to restore Nigeria to democracy largely due to the political turmoil that followed which the interim national government failed to manage. The fourth republic was constituted on May $29^{\text {th }}, 1999$ and it continued till date. It also has its challenges ranging from election malpractices, bad governance, and majority tyranny over minority rights, political party indiscipline, abuse of power, constitutional breaches, amongst others. These have affected adversely democratic stability and consolidation.

In Nigerian ridiculous journey with democracy, the fundamental question that stands out is: How far has the masses benefitted from this 'Nigerian Democracy'? Is everyone given the opportunity to participate, and freely exchange ideas through 
Ogirisi: a new journal of African studies vol. 15s 2019

discussion, debates and the likes? As we show how Nigerian leaders/leadership have practiced democracy or thrived over the years, we through democratic principles and examples know or affirm whether it is well practiced or denied. We shall know if there is really separation of power in Nigerian democratic leadership? How much checkmating has been done? Are the judiciary and the house of assembly really doing the work as expected? And since democracy is the government of the people, how much have the people contributed to making their leaders work well. How genuine is the electoral process of voting for their leaders? In what follows, we shall outline the conceptual clarification of terms.

Leadership: Leadership is an action of leading a group of people or an organization, while political leadership is a concept central to understanding political processes and outcomes, yet its definition is elusive. Many disciplines have contributed to the study of leadership including political theory, history, psychology and management studies. Political leadership reviews the contribution of these disciplines alongside with discussion of the works of classic authors such as Niccolo Machiavelli, Max Weber and Robert Michels.

Democratic Leadership: Democratic leadership is shared leadership where group members participate as everyone is given opportunity to participate and ideas are exchanged freely and discussion is encouraged, however, under the control and guidance of the leader of the group.

\section{Democracy}

In western Philosophy, the concept democracy, stems from the two Greek words, "demos" meaning "the people", and "Kratein" which refers "to rule". It is a system of government in which the people exercise the governing power either directly or through representatives periodically elected by themselves. In democracy, supreme or ultimate power is vested in the people and exercised directly by them or by their agents under free electoral system. In democracy, decision making system is based on people's majority opinion. And majority rule with minority right protected and represented. It is government by election and not selection. 
Uzondu: Assessing Nigerian Political Leadership with a Democratic Paradigm

Aristotle defined democracy as "The rule of the many for the good of the poor" as opposed to oligarchy which is "The rule of the few for the good of the wealthy"1

In the classical definition of Abraham Lincoln (on November 19, 1863 at union cemetery in Gettysburg, Philadelphia), democracy is: "government of the people, by the people, and for the people". It is a,

Political system in which the people of a country rule through any form of government they choose to establish. In modern democracies, supreme authority is exercised for the most part by representatives elected by universal suffrage. The representatives may be supplanted by the electorate according to legal procedures of recall and referendum, and they are, at least in principle, responsible to the electorate. $^{3}$

Modern democracy is representative, and is an acceptable fact by any rational human being in our populated and pluralistic world. However, democratic governments assume different forms based on a nation's political culture. Most countries like the United States, Nigeria, etc., distinguish between the Executive and legislative arms of governments and both the president and legislators are elected by the populace. Whereas in typical constitutional monarchies like the United Kingdom and Norway, only the legislators are elected, and it is from their ranks that a cabinet and a prime minister are chosen ${ }^{4}$

The beauty of democracy stands out when compared with other forms of government such as dictatorship, oligarchy or monarchy. "In these rival forms a single person or a select group rules. With democracy this is not so. The people themselves rule and they rule themselves. The same body is both ruler and ruled". 5 Democracy as a system of government has institutions that promise to guarantee the people's self-rule and attainment of the common good. So, democracy is a form of government that best protects human rights because it is the only one based on recognition of the intrinsic worth and quality of human being. It recognizes the masses for it is the masses that elect their representatives.

Democracy is characterized by: 
- Rule by the majority

- The rights of all the citizens are equal

- There is right to dissent and disobedience

- And it provides norm for political participation.

Similar to these characteristics are the basis for democracy, which include:

- Good government policies that must reflect what people want.

- Quality information on the government and debates will also be available

- Government of the majority

- Constitution is seen as the basic rule book or supreme rule of the law.

- Citizens are of equal rights.

\section{Essential Elements of Democratic Government}

\section{The Rule of the Law (Constitution)}

A constitution is an instrument of government made by the people, establishing the structure of a country, regulating the powers and functions of government, the rights and duties of the individual and providing remedies for unconstitutional acts. ${ }^{6}$ In a democratic government, constitution is necessary to properly set out the structure of the country, the powers and duties of government, rights and duties of the individual and provide remedies for unconstitutional acts. Without a constitution, whether written or unwritten, to regulate government, to set out the fundamental objectives, goals and direct principles of a country, the national life and indeed personal lives of the people would be subject a lot of arbitrary actions from government.

Government action would be according to the Whims \& Caprices of the ruler, pubic authorities and their agents. Rights and duties would be meaningless. Truth, justice and equity would fall to the group. Lawlessness chaos and directionlessness would reign in such country, until constitution and democratic rule is restored under the fear of God. Government must be according to civil laws and not according to men. 
As a doctrine, it means observance and supremacy of civil laws; that is, laws which are reasonably justifiable in a democratic society. It is the application and respect of civil or regular laws in a country. Civil law is opposed to draconian, oppressive and arbitrary laws. It is rule of right and not rule of might. As a doctrine, it means observance and supremacy of civilized laws, the absence of arbitrary laws and arbitrary actions. It is worthy to note here that the problem with Nigerian political democratic leadership started with the constitution. This is because the 1999 constitution in use was drawn by and during the military regime.

\section{Equality before the Law}

Rule of law means Equality of citizens before the law, and not favouritism. The law is an ass, does not know his master. No immunity clause. The law is above all. All persons in society should be equal and subject to the law of the land. The law should be applied equally to both the rulers and the people except for the privileges permitted by the constitution or other law, for certain public officers during their term of office. (For instance, judicial immunity and diplomatic immunity) In democracy, everybody is equal as far as the law and the constitution are concerned. So, by equality we mean not of status or origin but of opportunity, relevant functions and social participation.

Rule of the law means action according to the law, respect for the decision of court and is to be obeyed except if it is manifestly unjust, illegal or contrary to the rule of the law. Rule of the law mean government according to civil law and respect for human rights. Rule of law means operation of a constitutional and democratic system of government.

\section{Supremacy of Law}

It is the same with the term "Rule of the law" which is observant and supremacy of civil or regular laws. A civil law is a law which is reasonably justifiable in a democratic society. Example, Under 1999 constitution, subject to rule of law. 


\section{Common Good}

By common good is to be understood "the sum total of social conditions which allow people, either as groups or as individuals, to reach their fulfillment more fully and more easily. ${ }^{7}$

\section{Majority Rule}

With the emergence of a theory of human rights beginning in the $17^{\text {th }}$ century and its explicit development in the writings of Thomas Hobbes and above all, John Locke the way was prepared for conception of democracy in which the principle of majority rule was a necessary but not a sufficient condition. The will of the majority was to enjoy democratic legitimacy only if it was an expression of freely given consent.

Majority could do everything except deprive minorities of their civil rights, including freedom of speech, of the press and of the assembly and the right to a fair trial, the exercise of which might enable the minority to win over the electorate and come to power. Thus Sidney Hooke Writes:

Since unanimity among human beings about matters of great concern is impossible, the majority principle, in so far as it truly respects human rights is the only one that makes democracy a viable alternative to tyranny. (whether ancient or modern) ${ }^{8}$

\section{Fundamental Human Rights (Respect for Individual Liberties)}

The major features of modern democracy include individual freedom which entitles citizens to the liberty and responsibility of shaping own careers and conducting their own affair. Equality before the law, universal suffrage and education. These features have been proclaimed in great historic documents e.g. US declaration of independence, which asserted the right to life liberty, and the pursuit of happiness. The French declaration of the rights of man and of the citizen which affirmed the principle of civil liberty and equality before the law.

When we talk political liberty, we mean freedom, essential liberty includes: freedom of speech, of conscience, of press, association and assembly etc. J.S. Mill define liberty as "protection against the tyranny of the political rulers. ${ }^{9}$ Liberty is against 

governmental paternalism where by government force us to do what it thinks best for us, however, it is against individual autonomy. This exists because the rulers were conceived as in a necessarily antagonistic position to the people whom they ruled. Their power was regarded as necessary but also as highly dangerous, is a weapon which they would attempt to use against their subjects no less than against external enemies.

Liberty is all about limitation of the power which the ruler should be suffered to exercise over the community. This is because sometimes people who exercise power claim not to be the same with the ruled. Also in democratic republic sometimes, they succeed in making themselves the accepted majority. Thus "Tyranny of the majority". ${ }^{10}$

\section{Freedom of Press}

Here, we talk of communication and it is especially difficult to define the role of the press and other mass-media in a democratic society. Everyone believes that the press should be free within the confines of laws against personal libel, the scope and severity of which vary from country to country. But beyond this, the issue of ownership of the press is crucial to determining its degree of freedom and in responsibilities to the society in which if functions. For obvious reasons a free press cannot be a government press. In democratic countries the press is usually privately owned, yet the very nature of this ownership sometimes shapes its news or may result in the exploitation or serves for sensual purposes. Ideally, a free press should be a responsible press, responsible to truth, balanced fair and careful to distinguish between report of facts and statements of political opinion, but these terms are difficult to define - let alone realize - to everyone's satisfaction. In some countries large institutions such as political parties, trade unions, churches, interest group and social movements are encouraged to publish their own newspapers, so that a free press consists in freedom to publish newspapers with plural commitments.

Education - The role of the press in a democracy is one facet of the role of education in a democratic society. If one takes seriously the democratic ethical ideal of equality of concern for all individuals to develop themselves, the community must accept the responsibility of 
Ogirisi: a new journal of African studies vol. 15s 2019 providing educational opportunity to all of its members who can profit from it. This goes beyond the necessity of providing education on which the exercise of intelligent citizenship depends. It extends to preparing individuals for the careers appropriate to their potential talents.

\section{Participatory Politics}

For existence of an effective democracy the active participation of the citizens in the processes of government is needed. Participation is all the more essential as government grows in size and complexity and as individual citizens may be tempted to succumb to a feeling of ineffectiveness in the face of anonymous forces controlling their destiny. The result may be wide-scale apathy and a decay in democratic vitality, even when democratic forms are preserved.

\section{Election (Periodic, Free and fair elections of representatives)}

Election is a process of choosing somebody. "Is a procedure that allows members of an organization or community to choose representatives who will hold positions of authority within it"11

The most important elections select the leaders of local, state and national governments. The chance to decide who will govern at these levels serves as an opportunity for the public to make choices about the policies, programs and future directions of government action. At the same time elections promote accountability. The threat of defeat at the polls exerts pressure on those in power to conduct themselves in a responsible manner and take account of popular interest and wishes when they make their decisions.

Elections are held at regular intervals and should be free and fair. The responsibility for organizing elections rest largely with state and local governments. State laws specify how elections are to be administered, determine the boundaries of electoral districts and specify the qualifications of candidates. State, country and boards establish and staff polling places and verify the eligibility of individuals who come to vote. We have primary election and general election. In election, one can talk of voting rights, voters' participation, voters' registration and electoral systems. 
Uzondu: Assessing Nigerian Political Leadership with a Democratic Paradigm

\section{Existence of Opposition Political Parties}

The opposition parties act as watchmen of the ruling party, points out its errors and weakness.

- They oppose government policies and actions which are not in the interest of the nation.

- It ensures that government does not go beyond its constitutional powers.

- It strives to protect the interest, rights and freedoms of the people by keeping government activities under scrutiny.

- It offers a healthy competition to the government by coming with alternative views and answers to the problems of the country.

- And with the help of pressure groups such as labour unions, civil society groups, students and so forth, they try to influence the government to change their unfavourable decisions and actions.

They carefully assess government policies and actions and makes constructive criticisms and they act as check and balance; there by making the ruling party not to be complacent but alive to its constitutional responsibilities and the general welfare of the people. ${ }^{12}$

\section{Systems of Democracy}

\section{Presidential and Parliamentary}

Presidential system is a system of government where all executive powers are vested in a president who is the head of state and head of government. The president exercises the executive powers of government either directly by himself or through the vice-president, ministers or other officers in the public service of the country. He maintains the constitution and applies the laws made by parliament. The president is responsible to parliament which may investigate and impeach him for gross misconduct and he is also responsible to the people who are the sovereign power in a country and who may not renew his mandate at election, but vote him out of power. Countries operating presidential system of government include: The United States of America, Nigerian, Ghana, Kenya and South Africa. 
A parliamentary, cabinet or west minister system of government is one where all the executive powers are in a prime minister who is the head of government and head of the majority party or ruling party. The prime minister and the entire ministers in his cabinet are all members of the same party or coalition of parties. In this sense, the prime minister is a primus inter pares (first among equals). In a cabinet system, there is no complete separation of powers, nor completes fusion of powers.

\section{Unitary and Federal Systems}

Unitary system is where political authority inheres in the central government, which is constitutionally authorized to determine the limited powers as well as the geographic boundaries of sub-national associations such as states or regions. In federal system, authority is constitutionally divided between the central government and the governments of relatively autonomous sub-national entities. Among the countries that have adopted includes, United States, Switzerland, Germany, Austria, Spain, Canada, Australia, and India.

\section{Proportional and Winner-Take all Systems}

Electoral arrangements vary enormously. Some democratic countries divided their territories into electoral districts, each of which is entitled to a single seat in the legislature, the seat being won by the candidate who gains the most votes - hence the terms first past the post in Britain and winner take all in the United State. Systems of proportional representation are designed to ensure closer correspondence between the proportion of votes cast for a party and the proportion of seats it receives. With few exceptions, Continental European countries have adopted some form of proportional representation, as have Ireland, Australia, New Zealand, Japan, and South Korea. Winner-take-all systems remain in the United States, Canada, and for parliamentary elections, in Britain.

\section{Two Party and Multiparty Systems}

Proportional representation does not favour large parties over smaller ones, as does the winner-take-all system, in countries with proportional representation. For this reason, there are almost always three or more parties represented in the legislature, and a coalition government consisting of two or more parties is ordinarily necessary 
Uzondu: Assessing Nigerian Political Leadership with a Democratic Paradigm

to win legislative support for the government's policies. Thus the prevalence of proportional representation effectively ensures that coalition governments are the rule in democratic countries; governments consisting of only two parties, such as that of the United States, are extremely rare.

\section{Majoritarian and Consensual Systems}

Here, we talk of whether laws and policies can be enacted by a single relatively cohesive party with a legislative majority as is ordinarily the case in Britain and Japan, or instead requires consensus among several parties with diverse views as in Switzerland, the Netherlands, Sweden, Italy and elsewhere.

\section{Participatory Democracy in Africa}

Having seen that democracy as people's government is widely accepted government in the world. Many states or countries in Africa having gained independence from colonial rule in the later part of $20^{\text {th }}$ century, and as such adopted democratic political ideology without the full knowledge of its cumulative implication.

Today, most African countries that claim to practice democracy really create mimicking concepts of democracy. Corruption has been the bane of many underdeveloped African nations. Also, it is argued that neo-colonization, neo-imperialism and a negative face of globalization have been undermining Africa's development. And these vices are set in motion through the 'democratic political machinery and cultures' African states inherited from their colonial masters. Thus, there is always a problem beginning from the process of recruiting political leaders (called election) through the political leadership itself. The electoral process (or democratic process) in many African states like Uganda, Nigeria, Zimbabwe to mention a few is always inhibited by such identifiable factors like monetization of politics, one party hegemony and lopsided representative. ${ }^{13}$

Thus, there is the perception of politics as warfare and state as arena of conflict. On a more critical look, one identifies the pervasive nature of economic crisis in the region as a serious threat to participatory democracy. 
Ogirisi: a new journal of African studies vol. 15s 2019

Other factors that inhibit the progress of democratic process in Africa (Nigeria inclusive) include:

\section{Voter Registration}

This is a crucial issue, for sometimes, it is vulnerable to manipulations and is critical thereby positioning a political party to gain electoral advantage. To this extent, how the voters' registration is conducted by whom, when and where are germane to the pursuit of elections in Africa. Sometimes, there is fear of government manipulating registration to favour the ruling party. Also, alleged plans to under register and mass disenfranchise voters sympathetic to opposition parties in certain constituencies.

2. National identity and citizenship issue especially in border areas where it is problematic to determine citizens and where parties seek to inflate the register by recruiting people across the border. ${ }^{14}$

3. Election in Africa is prone to the problems of access to voting centers and the number of the centers that are accessible to the electorate. The voting centers are poorly popularized and the belated relocation of centers constitute problem to elections and confidence building. The voting system, open or secret, has been contentious in African elections.

\section{Money Politics}

This is evident in recent elections in Nigeria, Uganda, and others. Thus, William writes that massive use of money, gifts, promises of future material benefits are inhibitions to personal freedom, the right of choice and democratic practice. The monetization of election makes the voters right a cheap commodity and violates the sovereign status of the populace. ${ }^{15}$

\section{Democracy as seen in Nigeria}

Greek state that started the practice of participatory democracy is city-state and not nation state as in our country Nigeria. Nigeria is neither a Christian state nor a Muslim state but a Secular state. Nigeria is a Republic by constitution, for constitution gives one a kind of government that a state is. Nigeria is a federation that is, conglomeration of un-autonomous states (as opposed to co- 
Uzondu: Assessing Nigerian Political Leadership with a Democratic Paradigm

federation). The federation of Nigeria, as it exists today has never really been one homogeneous country; for its widely differing peoples and tribes are yet to find any basis for true unity. After the amalgamation of the Northern and Southern Nigeria in 1914 in the words of Madiebo "the only thing these peoples had in common became the name of their country". ${ }^{16}$

As we talk of Nigerian democracy, instead of having notion of types, we focus on the differences in standards that have been attained in time and place. To what extent has the Nigerian society realized the ideals of democracy as already stated above? In answer to this, we summarily put it that Nigeria is still too far in realizing the ideals of democracy as its electoral or democratic process is still characterized by monetization of politics, one party hegemony and lopsided representative system. In Nigerian political reality, there is multiplication of ballot papers, stealing of ballot boxes and there exists grass electoral malpractices in order to win election, inflation of population census where electoral staff admit people across the border as national identity and citizenship issues are not seriously checked. There is distribution of money, gifts and other promises of future material benefits just to buy people's conscience. These are Nigerian political realities or realism. There is a lot of dirty games in Nigerian democracy and is seen as a warfare. And is good to ask: Can an honest man practice honest politics in Nigeria? Although, there seems to be slight improvement in 2011 and in the last concluded FebruarylMarch 2019 election, as there was introduction of electronic/computer registration and real counting of citizen's votes in some places, but there were still so many irregularities, disenfranchisements of genuine voters by thugs, paid policemen and even military men. Thus, the hope of authentic process and dividends of democracy are still very far. When one calculates the years of independence and democratic government, (military intervention notwithstanding) one sees that our leaders have not meet up with the basic human needs of its citizen, not to talk of fundamental human rights and freedom/liberty opted by democratic ideology. Corruption has been the bane of Nigerian politics and political leaders. Unlike their western counterparts, democratic parties and expected benefits have made very sad news for Nigeria. 
Ogirisi: a new journal of African studies vol. 15s 2019

Finally, this distorted practice and institutional processes of democracy, alongside capitalist models of globalization, neocolonialism has turned Africa and Nigeria in particular, into state of political confusion, and loss of a fine-tuned democratic identity. Little wonder, scholars now demand new ideologies for civil rule in Africa and in Nigeria.

\section{Democratic Leadership/Paradigm}

Democratic leadership is shared leadership where group members participate as everyone is given opportunity to participate and ideas are exchanged freely and discussion is encouraged, however, under the control and guidance of the leader of the group.

Democratic leadership style is one of the most effective types and leads to higher productivity, better contributions from group members and increase group morale. So many countries in the world are now into democracy and democratic leadership.

African leadership may not be a good example of excellent democratic leadership as so many African leaders are corrupt. But, we can portray Julius Nyerere of Tanzania to have excelled in democratic leadership. His excellence started in his thoughts on party system and democracy. This philosopher-statesman was a man of great vision and strong belief in the role of the leading party in the relations between the people and the state. He considered the leading political party, an embodiment of people's wishes and aspirations, as an agent of their articulation and cushion against excesses of state power ${ }^{17}$. He promoted a political philosophy called Ujamaa. He was not corrupt in his leadership. If Nigerian leaders and leading party will emulate and implement such, our nation will really be great.

Nelson Mandela is another African democratic leadership paradigm. Under Nigerian leadership and development, one sees tribal, religious sentiments and discrimination, but Mandela in his democratic leadership was a man of peace, forgiveness, had a powerful presence and disarmed enemies with smile. He was a visionary leader, a man of positive thinking. He dismantled the legacy of Apartheid by tackling institutionalized racism and fostering racial reconciliation. His leadership statement could be seen in this speech at Rivonia trial in 1963. "I have fought against white domination and I have fought against black domination, I have cherished the ideal of a democratic and free society in which all 
persons live together in harmony and with equal opportunities, it is an ideal which I hope to live for and to achieve but if need be, it is an ideal for which I am prepared to die." 18 Nelson Mandella never wavered in his devotion to democracy, equality and learning. Despite terrible provocation, he never answered racism with racism. His life is an inspiration to all who are opposed to oppression and deprivation.

Another world example is Dwight D. Eisenhower, the republican president of United states during $2^{\text {nd }}$ world war. He was known to have used strategic approach to solving military and diplomatic issues. As supreme allied commander during the war, he didn't command automatically, he is known with his quote "together, we must learn how to compose differences, not with arms, but with intellect and decent purpose". He exemplifies his wish to create more harmony and consensus in everything society does. He wanted to involve other people in the decision making and sought out expert opinions from others. In Nigeria, not minding so many presidential aides and special advisers, not much real or true change is experienced.

Abraham Lincoln is another famous example of democratic leadership. He became a leader in the new Republican Party and gained national attention in 1858 in debate with national democratic leader Stephen A. Douglas. In his democratic style, one finds empathy or ability to share the feelings of another, emotional intelligence, the ability to mix with others. He also has skills to persuade and lead teams. During American civil war, he was said to have formed a cabinet composed of his political rivals in whom he put his faith.

George Washington - when guiding the U.S government, he appointed strong leaders to his staff. His decision not to serve a third term exemplified a democratic leader who knows when to pass the torch. He was not like some African greedy leaders who still want to continue ruling, not minding the tenure ship and age.

John F. Kennedy - a charismatic leader at heart, had both laissez-faire and democratic leadership styles. By laisser-faire, we mean a delegative leadership in which leaders hands off and allow group members to make decisions. 
Thomas Jefferson -A statesman, diplomat and a Lawyer, third president of US (1801-1809). He was both an authoritarian and democratic leader.

Jimmy Carter $-39^{\text {th }}$ US president, a politician and a philanthropist, a former naval commander. He exemplified both the qualities and pitfall of democratic/participative leadership styles.

Finally, apart from Political democratic leadership, we mention some companies known for their democratic leadership. They include: Major Clinics, Google Amazon.com, Twitter and Ginni Rometty. Also, democratic leadership can also be seen in some universities, building sites and the likes.

\section{The Way Forward for Nigerian Leaders}

1. Our Nigerian leaders are to lead in accordance with democratic principles. Kurt Lewin et al identified three core elements of democratic leadership. One is leaders should expect the subordinates to report tasks (done and to be done) to them. Again, self-confidence is needed by the leaders towards their subordinates, no constant supervision. Finally, subordinates are expected not to work alone, they should involve others. This is democracy.

2. Justice is needed in Nigerian leadership. Justice as given each man his due, equitable distribution of goods and services, the dividends of democracy in terms of money and other developmental infrastructure.

3. Principle of subsidiarity is needed. i.e. principle that matters ought to be handled by the smallest, lowest or least centralized competent authority should be handled by them. One has to do his own function and not allotting for oneself the task that belongs to another. This is mostly seen in Nigerian government, where the state governors will take the fund that belongs to local government and start to execute the work local government chairmen are supposed to do themselves.

4. Bad leadership and corruption. If Nigerian government means to fight corruption, no individual or party system is a sacred cow or is above the law and immunity clause should be removed so that the law takes its cause on everyone.

5. Checks and balances. Here, we advocate for separation of powers into executive, legislative and judicial arms of 
government to check each other's excesses. This exercise is not effective in the Nigerian democratic leadership as often the executive arm of the government is always with excess power. Again, as there are divisions of power within the legislative arm (upper and lower houses) we expect them to check each other always. Again, the $3^{\text {rd }}$ check is that the legislative has to check activities within the states or province, and verse versa. $4^{\text {th }}$ check is on the powers of lawmakers themselves, they are accountable to the people that voted them, otherwise they can be recalled or voted out.

6. As the judicial arm of the government is the last hope of a common man, there is great need for them to be independent and they need to be empowered financially so as not to be slaves to the executive arm that appoints them.

7. During election, much efforts should be made not to disfranchise genuine citizen that came out to vote as it happened at Lagos, Port-Harcourt and in some other places during the last Februaryl March election.

\section{Critical Evaluation}

Since the adoption of modern government in the African continent, the quest for a viable and healthy democratic practice has been a serious problem as far as African leaders are concerned. Leaders of the world power especially those of western nations and political analysts are emphasizing the need to have democracy as the "open sesame" to effective government. That is, as an easy way of securing access to what is usually inaccessible; thus, democracy leads to effective government, but the practice of this ideology in Africa has not brought much dividend.

Democratic leadership is needed most in Nigeria leadership. Where the basic principles or regulative ideals of democracy will be evident, that Nigeria people will have a right to a controlling influence over public decisions and decision-makers and that they should be treated with equal respect and as of equal worth in the context of such decisions. Nigerian citizens are expected to organize themselves collectively to achieve certain goals themselves and with the help of their leaders, democracy and democratic leadership will promote supremacy of the people as its government of the people, for the people and by the people. It will promote or bring about the 
actualization of public opinion through representative government. It will promote the supremacy of the constitution and promote checks and balances among various arms of the government; promote stable government, equitable sharing of economic resources and guard fundamental human rights. Democratic leadership is not only vital in Nigerian government leadership but it is needed in our companies, institutions and universities and even in religious organizations and in churches for effective leadership. Such leadership promotes honesty, intelligence, courage, creativity, competence and fairness.

There is another side of democratic leadership. Nigerian democracy and leadership is expected to be progressive so to be delivering democratic dividend to Nigeria populace. Thus, democracy is always in flux and will never be fully realized because democracy is really a matter of degree. And there are some drawbacks or setbacks as far as democratic leadership is concerned. They include delay or slow development due to a lot of protocols and due processes and this makes some works very expensive, poor decision making due to lack of experts by the group and overriding of individual or minority rights and opinions.

Some African nationalist thinkers like Nkrumah, Senghor, Nyerere and others have even proffered African communalism as an ideology that is suitable as an African way (of life). African communalism is the mode of life of the traditional Africans characterized by humane living. By humane living, we mean a way of life emphatically central upon human interests and value. It manifests a mode of living evidently, characterized by empathy, consideration for others and compassion for human life. Above all, it stresses oneness and unity of purpose, but when one looks at communalism, one sees that integration of its vital and credible stances as it affects democratic practices will lead to quicker delivery of democratic dividend in Africa, especially with recourse to its communal bodies, its enabling environment and its communal spirit.

\section{Conclusion}

Democracy or democratic leadership, which is an offshoot of Greek city - states assembly, has not been yielding the expected dividends or benefits in Africa and Nigeria inclusive, owing to the problem of enlightenment, the state of economy and education. Through 
Uzondu: Assessing Nigerian Political Leadership with a Democratic Paradigm research, we have found out that not minding some setbacks in this democratic leadership ideology, it is still the most effective type and it leads to higher productivity, better contributions or participation from members and increased group morale. Democracy is still government of the people, for the people, by the people. Finally, democratic leadership should always be viewed through the lens of the citizen for it is she who provides government institutions with moral authority.

*Ignatius C. Uzondu, Ph.D, Department of Philosophy, Nnamdi Azikiwe University, Awka, ic.uzondu@unizik.edu.ng 


\section{ENDNOTES}

1. Aristotle Politics, III, V. 7; (New York: Penguin Books Ltd. 1981)

2. A. Lincoln "The Gettysburg Address, 1863" The New Right of Man, ed. John E. Lewis, (London: Robinson, 2003), P. 421.

3. R.M. Pious "Democracy" Microsoft ® Student Encarta 2008 $\{D V D\}$. (Redmond, WA: Microsoft corporation 2007).

4. R. M. Pious, Ibid.

5. H. Ross "Democracy" in Routledge Encyclopedia of Philosophy.

6. E. Malemi The Nigerian Constitutional Law with Fundamental Rights (Lagos:Prinecton Pub. Co. 2010) p.1.

7. The Catechism of the Catholic Church (Nairobi Kenya: Paulines Publications African, 1995) No. 1906, p. 457.

8. S. Hook "Democracy" Encyclopedia Americana (International edition) (USA: Grolier 2001) vol. 8 pp. $684-685$.

9. J.S. Mill "On Liberty" in Great Books of Western World, P. 267.

10. Ibid, p. 269.

11. B. Girisberg "Election" Microsoft ® Student 2008 (DVD) (Redmond, WA: Microsoft Corporation 2007).

12. E. Malemi, The Nigerian Constitutional Law with Fundamental Rights, Ibid pp. 37 -

13. D. Seteolu "Elections and the Politics of Participatory Democracy in Africa", www.ajol.inf/index.php/Ihr/article/view/32557

14. A Jinadu (1997) "Matters Arising: African Elections and the problem of Electoral Administration", African Journal of Political Science, Vol. 2, No. 1, pp. 3-11.

15. M. William (1997) Money and power in Uganda's 1996 Elections, African Journal of Political Science, Op. Cit, 168169.

16. A.A. Madiebo, The Nigerian Revolution and the Biafran War. (Enugu: Fourth Dimension Publishers, 1980).

17. D.S Kapinga 'Mwalimu Nyerere's “Thoughts on party system and democracy" Tanzania Journal of Development studies.

18. N.R Mandela, Long Walk to freedom - the autobiography of Nelson Mandela, ( $2^{\text {nd }}$ edition) Abacus Publishing, 1995. 438. 